\title{
BIOCHEMICAL ACTIVITY OF DI- AND POLYAMINES IN THE GREEN ALGA CHLORELLA VULGARIS BEIJERINCK (CHLOROPHYCEAE)
}

\author{
ROMUALD CZERPAK, ANDRZEJ BAJGUZ ${ }^{1}$, AliCJA PIOTROWSKA ${ }^{2}$, \\ Renata Dobrogowska, Marzena MateJczYK, WoJcIECH WiESŁAWSKi \\ University of Bialystok, Institute of Biology \\ Swierkowa 20 b, 15-950 Bialystok, Poland \\ 1 e-mail: abajguz@uwb.edu.pl \\ 2e-mail: alicjap@uwb.edu.pl
}

(Recived: May 21, 2002. Accepted: January 6, 2003)

\begin{abstract}
This study concerns on the influence of diamines (agmatine, putrescine) and polyamines (spermine, spermidine) upon the growth and the content of chlorophyll $a$ and $b$, monosaccharides and proteins in the cells of alga Chlorella vulgaris Beijerinck (Chlorophyceae). In the experiments agmatine, putrescine, spermine and spermidine in the range of concentrations $10^{-6}-10^{-3} \mathrm{M}$ were used. At the concentration $10^{-3} \mathrm{M}$ and the 1 st day of cultivation, they have a toxic effect on growth of the algae. It was found that di- and polyamines used within the range of concentration $10^{-6}-10^{-4} \mathrm{M}$ stimulate the growth and the contents of analysed biochemical parameters in the cells of $C$. vulgaris. The most stimulating influence on metabolism of the alga was demonstrated by spermidine and putrescine at concentration of $10^{-4} \mathrm{M}$. Agmatine and spermine were characterised by a lower biological activity than spermidine and putrescine demonstrated the most stimulating influence.
\end{abstract}

KEY WORDS: Chlorella vulgaris, di- and polyamines, growth, chlorophylls, monosaccharides, proteins.

\section{INTRODUCTION}

Di- and polyamines (PA) as polycation nitrogen compounds commonly occur in the cells of all pro- and eucaryotic organisms. They belong to the specific cellular regulators of growth and physiological - metabolic processes but differ essentially in their action from the typical hormones. They act together with plant and animal hormones activating the growth and metabolism of organisms. They affect directly or indirectly numerous biochemical transformations of cells particularly the metabolically very active, as: formative, reproductive and parenchyma cells (Galston and Kaur-Sawhney 1982; Tabor and Tabor 1984; Smith 1985; Bothma and Dubery 1991; Niklas et al. 1998; Bajguz and Czerpak 1999; Minocha et al. 1999).

As we know, di- and polyamines occur in almost all cellular organelles chiefly in the nuclei, chloroplasts, ribosomes, cytoplasmic membranes and the walls of young cells. A markedly higher level of polyamines was noted in decondensed regions of chromosomes and nucleoli replicatively and transcriptively active so, they participate in the activation of replication, transcription and translation. In chloroplasts di- and polyamines stimulate the photosynthetic process in both its phases - the dark and the light as we-
11 as activating the primary and secondary growth of the cell wall. These compounds stimulate the active transport of metabolites, the functioning of enzymes and ion pumps localised in the cellular membranes (Kaur-Sawhney et al. 1982; Shih et al. 1982; Smith 1985; Pjon et al. 1990; Gniazdowska-Skoczek et al. 1994; Bagni 1997; Kakkar et al. 1997/98; Laitinen et al. 1998; Bajguz and Czerpak 1999; Czerpak and Bajguz 1999; Desideiro et al. 1999; Kotzabasis et al. 1999).

Because of their polycation properties, di- and polyamines readily enter into the relevant physicochemical interactions with DNA, mRNA, tRNA and with secondary metabolites like phospholipids, phosphosaccharides, phosphoproteins, receptors and other specific proteins functioning as regulators of cellular metabolism. Di- and polyamines together with positive amine groups form chemical compounds with the negatively charged phosphate, carboxyl or sulphone groups found in nucleic acids and many proteins, lipids and saccharides. This type of compounds causes conformation changes in the micromolecules and membranous structures of the cells and as a result in their physiological-biochemical activity (Shih et al. 1982; Tabor and Tabor 1984; Schuber 1989; Maccarrone et al. 1999; Bajguz and Czerpak 1999). 
A few reports (Smith 1985; Dureja-Munjal et al. 1992; Van den Broeck et al. 1994; Ye et al. 1994; Ponappa and Miller 1996; Bagni 1997) showed that di- and polyamines activate the synthesis of secondary cellular signal transmitters, e.g. triphosphoinositol and diacylglycerol mainly by stimulating the synthesis of their direct precursors, the phosphoinositides. Their action within the cells is auxiliary and complementary to the effect of phytohormones and other regulators stimulating plant physiological-metabolic processes (Smith 1985; Bothma and Dubery 1991; Gniazdowska-Skoczek et al. 1994; Ponappa and Miller 1996; Bagni 1997; Davis 1997; Sarjala et al. 1997; Czerpak and Bajguz 1999).

In addition, PA e.g. spermidine and spermine activate serine-treonine kinase in the cell nucleus. This is of great importance in the regulation of numerous metabolic transformations, whose mechanism of action consists in phosphorylation and dephosphorylation of specific cellular proteins and lipids. PA stabilize the cell membranous structures and their function, as well, as inhibit ethylene and abscisic acid synthesis (Smith 1985; Scoccianti et al. 1989; Bothma and Dubery 1991; Dureja-Munjal 1992; Van den Broeck et al. 1994; Ye et al. 1994).

Di- and polyamines commonly occur in micro- and macro-organisms. Considerable amounts of putrescine are contained in the cells of bacteria, Cyanophyceae and algae, particularly those of the Chlorophytae, among others the Chlorella and Scenedesmus. In vascular plants, on the other hand, there is usually a predominance of spermine and spermidine and less agmatine and putrescine (Galston and Kaur-Sawhney 1982; Tabor and Tabor 1984; Kakkar et al. 1997/1998; Bajguz and Czerpak 1999).

To date, the studies of biologically active di- and polyamines have concerned their presence mainly in vascular plants and, in a few cases, algae. For this reason comparative studies of the effect of diamines (agmatine, putrescine) and polyamines (spermine, spermidine) on some biochemical parameters in an unicellular Chlorophytae, Chlorella vulgaris, chosen as a model experimental object have been undertaken.

\section{MATERIAL AND METHODS}

\section{Culture conditions}

Chlorella vulgaris Beijerinck (Chlorophyceae) was grown under controlled condition at $25 \pm 0.5^{\circ} \mathrm{C}$. Illumination was supplied during a $16 \mathrm{~h}$ photoperiod $(8 \mathrm{~h}$ dark period) by a bank of fluorescent lights yielding a photon flux of $50 \mu \mathrm{mol} \cdot \mathrm{m}^{-2} \cdot \mathrm{s}^{-1}$ at the surface of the tubes. Permanent synchronous growth was established according to the method of Pirson and Lorenzen (Pirson and Lorenzen 1966), in conditions developed by Sayegh and Greppin (Sayegh and Greppin 1973). The culture medium used was modified Knop's medium. The $\mathrm{pH}$ of the medium was adjusted to 6.8 with $1 \mathrm{~N} \mathrm{NaOH}$. The Chlorella vulgaris cells were cultured in an Erlenmeyer flask $(500 \mathrm{ml})$ containing 250 $\mathrm{ml}$ of medium, and shaken at $50 \mathrm{rpm}$ in a rotary shaker.

\section{$D i$ - and polyamines}

Diamines (agmatine, putrescine) and polyamines (spermine, spermidine) were purchased from Sigma (St. Louis, MO; USA). These compounds were prepared as $10^{-3} \mathrm{M}$ aquatic stock solutions and stored at $-20^{\circ} \mathrm{C}$. The appropriate amount of di- and polyamines stock solution for the strongest solution was transferred directly into culture medium and weaker solutions were prepared by serial dilution.

\section{Determination of the growth of algae}

The growth of the culture was estimated by direct counting of cells in the growth medium using the Bürker chamber. The number of cells of $C$. vulgaris was expressed as $10^{6}$ in $1 \mathrm{ml}$ of the alga culture.

Determination of content of chlorophylls, monosaccharides, water-soluble proteins

The determination of chlorophyll content followed homogenisation of the alga fresh weight in methanol. The absorbance of the extract was measured with a Shimadzu UV-Vis 1201 spectrophotometer at 653 and $666 \mathrm{~nm}$. The amount of chlorophyll $a$ and $b$ present in the extract were calculated according to the equation of Wellburn (Wellburn 1994).

For sugar determination, the algae were first collected by centrifugation of $10 \mathrm{ml}$ culture samples. Sugar concentration in the cell excretion was determined using the Somogyi method (Somogyi 1954).

The measurement of protein content was done by extracting the alga pellet overnight in $0.1 \mathrm{~N} \mathrm{NaOH}$ at $4^{\circ} \mathrm{C}$. Concentration of protein was determined by the method of Lowry (Lowry et al. 1951) with a protein kit calibrated with bovine serum albumin as the standard.

\section{Replication and statistical analysis}

Each treatment consisted of 5 replicates and each experiment was carried out at least twice at different times. A minitab statistical package was used to carry out a one-way ANOVA. Significance was determined using $t$-tests and LSD values based on the ANOVA data.

\section{RESULTS AND DISCUSSION}

The green alga $C$. vulgaris was used to investigate the effects of diamines: agmatine (1-amino-4-guanidinobutane), putrescine (1,4-diaminobutane) and polyamines: spermine (N, N'-bis[3- aminopropyl]-1,4-butanediamine), spermidine (N-[3-aminopropyl]-1,4-butanediamine) on the growth (expressed as the number of cells) and the content of chlorophyll $a$ and $b$, monosaccharides and proteins. The results of the research presenting the contents of the analysed biochemical parameters in $C$. vulgarise are presented graphically in Figs 1-5. During the experiments di- and polyamines were used within the range of concentrations $10^{-6}-10^{-3} \mathrm{M}$. At the concentration $10^{-3} \mathrm{M}$ di- and polyamines have a toxic effect on growth of the unicellular green algae. It was recorded at the 1 st day of cultivation. The most stimulating influence upon the number of cells of $C$. vulgarise was noted by spermine at the concentration $10^{-6} \mathrm{M}$, particularly at the 3rd and 6th day of cultivation. Putrescine at $10^{-4} \mathrm{M}$ had a slightly weaker effect on the alga growth The lowest activity on the number of cells was found in spermidine and agmatine at concentration $10^{-4} \mathrm{M}$ throughout the whole 9 day period of $C$. vulgaris cultivation (Fig. 1).

Spermidine, putrescine and agmatine in the range of concentration $10^{-6}-10^{-4} \mathrm{M}$ stimulates chlorophylls, monosac- 

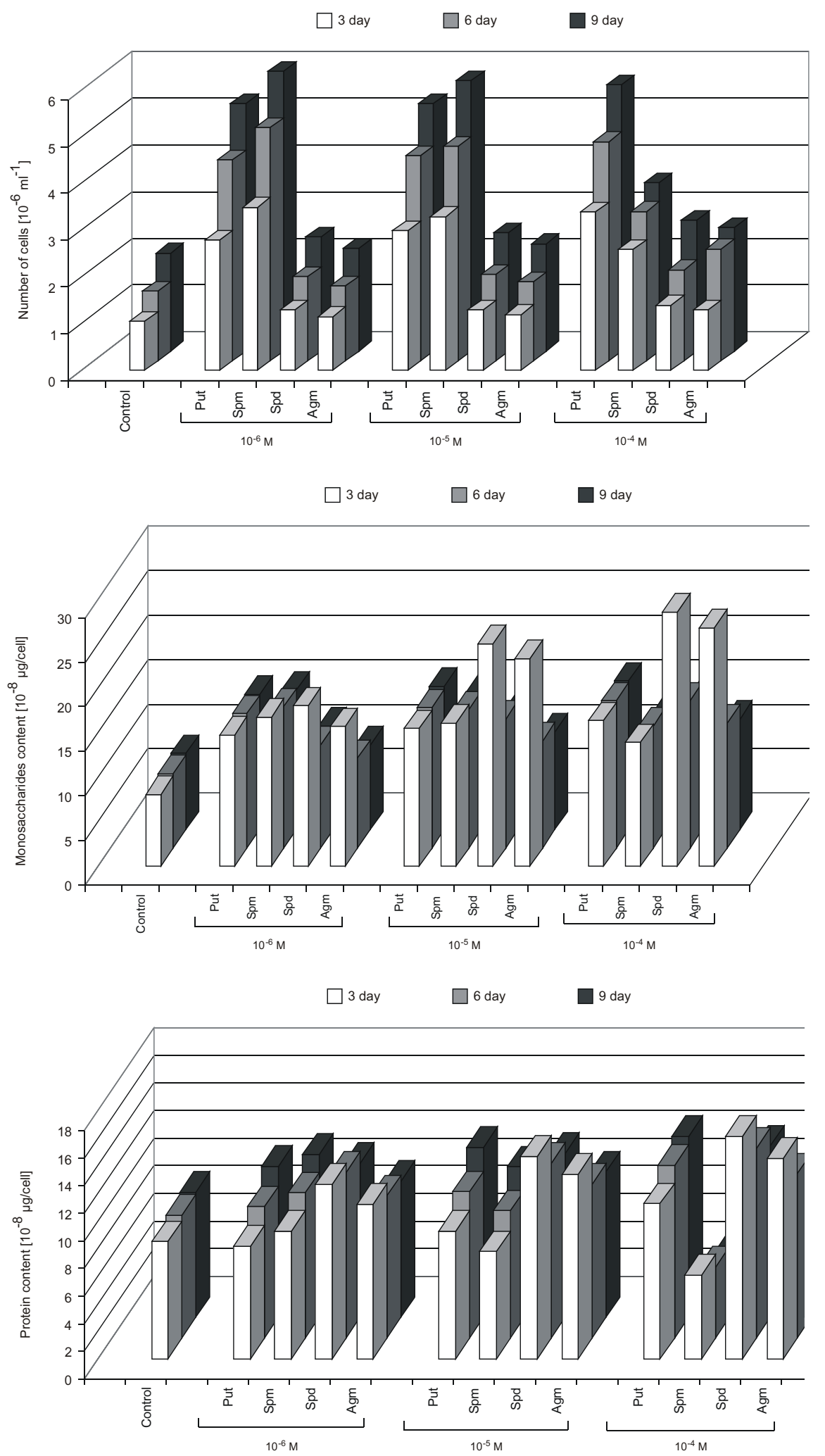

Fig. 1. Effect of putrescine (Put), agmatine $(\mathrm{Agm})$, spermine $(\mathrm{Spm})$ and spermidine (Spd) on the number of Chlorella vulgaris cells (expressed as $10^{6} \times \mathrm{ml}^{-1}, \mathrm{SE}<5 \%$ ).

Fig. 2. Effect of putrescine (Put), agmatine $(\mathrm{Agm})$, spermine $(\mathrm{Spm})$ and spermidine (Spd) on the content of monosaccharides in the cells of Chlorella vulgaris (expressed as $10^{-8} \mu \mathrm{g} \times$ cell $^{-1}, \mathrm{SE}<5 \%$ ).

Fig. 3. Effect of putrescine (Put), agmatine $(\mathrm{Agm})$, spermine $(\mathrm{Spm})$ and spermidine (Spd) on the content of protein in the cells of Chlorella vulgaris (expressed as $10^{-8} \mu \mathrm{g} \times$ cell $^{-1}, \mathrm{SE}<5 \%$ ).

charides and water - soluble proteins contents in the alga C. vulgaris. The maximum increase of the amounts of these biochemical parameters was observed under the influence of $10^{-4} \mathrm{M}$ in the mentioned above di- and poliamines. However, spermine displayed the greatest stimulative activity in a concentration of $10^{-6} \mathrm{M}$ in reference to the control culture devoid of exogenous di- and poliamines (Figs 2-5).

Our comparative studies made on the unicellular $C$. vulgaris, revealed that diamines (agmatine, putrescine) and polyamines (spermine, spermidine) exert a marked stimulating effect within the range of concentration $10^{-4}-10^{-6} \mathrm{M}$ on growth and metabolism of the green alga studied as an experimental model. The highest stimulating activity of the di- and polyamines studied was noted in a concentration of $10^{-4} \mathrm{M}$ on the number of cells and their content of water soluble proteins and monosaccharides on the 3rd day of the alga culture and on chlorophylls $a$ and $b$ on the 9th day of the culture. Putrescine, especially, at $10^{-4} \mathrm{M}$ concentration 

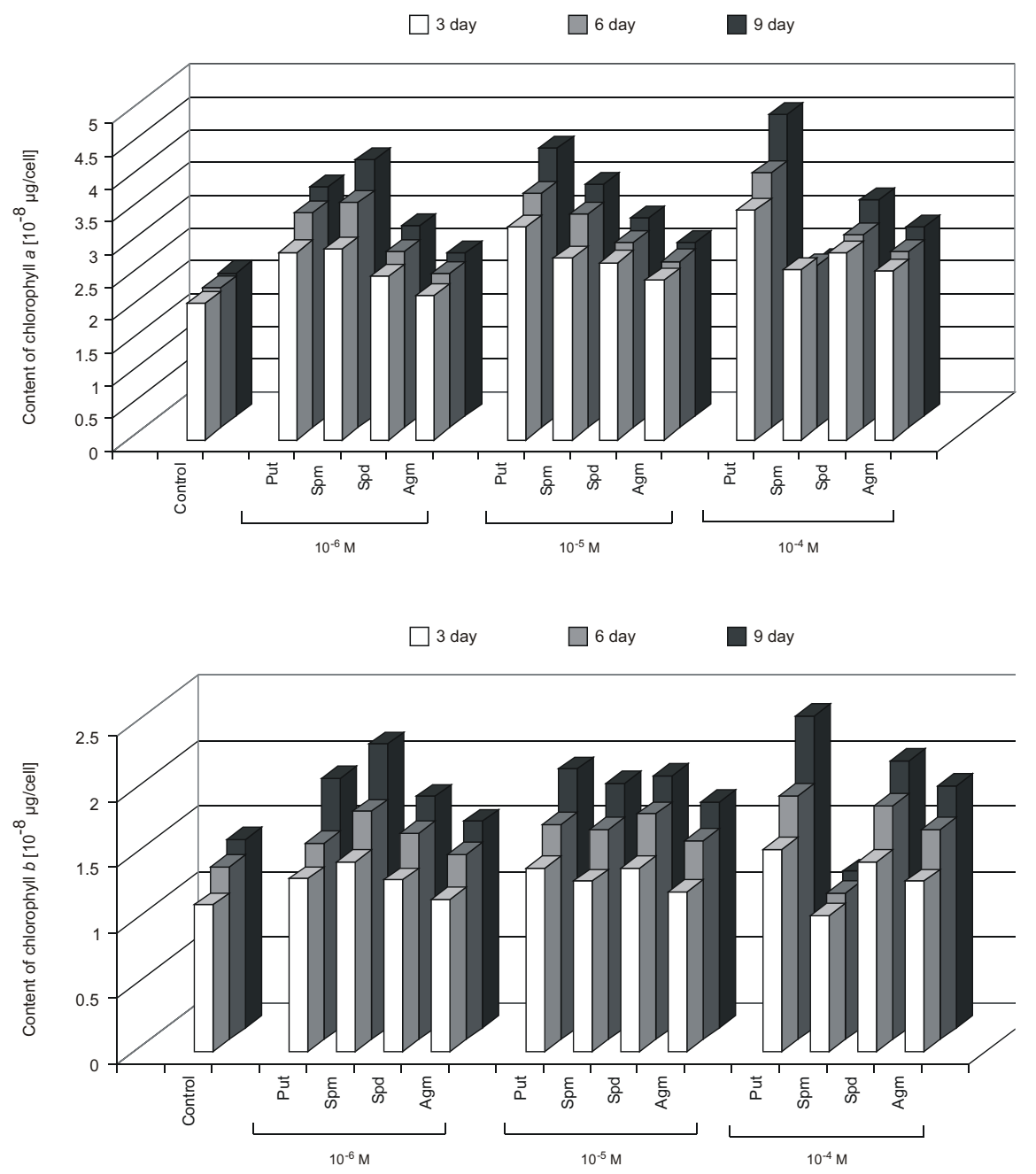

Fig. 4. Effect of putrescine (Put), agmatine $(\mathrm{Agm})$, spermine $(\mathrm{Spm})$ and spermidine (Spd) on the content of chlorophyll $a$ in the cells of Chlorella vulgaris (expressed as $10^{-8}$ $\mu \mathrm{g} \times$ cell- $\left.^{-1}, \mathrm{SE}<5 \%\right)$.
Fig. 5. Effect of putrescine (Put), agmatine $(\mathrm{Agm})$, spermine $(\mathrm{Spm})$ and spermidine (Spd) on the content of chlorophyll $b$ in the cells of Chlorella vulgaris (expressed as $10^{-8}$ $\mu \mathrm{g} \times$ cell $^{-1}, \mathrm{SE}<5 \%$ ). was found to have the strongest stimulatory effect on the content of chlorophylls $a$ and $b$. In this one case putrescine appears to be more active than other di- and poliamines. On the other hand, spermidine at $10^{-4} \mathrm{M}$ proved the highest stimulation of the content of the fraction of water - soluble proteins and monosaccharides in comparison to the control culture. The stimulative properties of agmatine in relation to the analysed biochemical parameters in $C$. vulgaris were slightly weaker than that of other di- and polyamines. As biochemically most active was found to be spermidine, as has been previously reported in studies carried out on vascular plants (Tabor and Tabor 1984; Smith 1985; Ye et al. 1994; Sarjala et al. 1997; Bajguz and Czerpak 1999).

It is well known that the physiological-biochemical activity of di- and polyamines is mainly due to their polycation structure. In all probability, the more number of amine groups in poliamine, the more metabolically active this compound is, because in this way it possesses greater biochemical possibilities to interact with nucleic acids, proteins, hormones and another metabolites characterised by regulating function (Van den Broeck et al. 1994; Davis 1997; Tiburcio et al. 1997; Laitinen et al. 1998; Desideiro et al. 1999; Kotzabasis et al. 1999). From the studies carried out on the $C$. vulgaris it was seen that the highest biological activity of spermidine results from the fact that it contains three amine groups of a cation character whereas the lowest activity is noted in agmatine with only one $-\mathrm{NH}_{2}$ group.

Under the influence of the optimal concentrations of agmatine, putrescine, spermidine in the concentration of $10^{-4} \mathrm{M}$ and spermine in $10^{-6} \mathrm{M}$ applied in the $C$. vulgaris culture no time correlation between stimulation of the chlorophyll $a$ and $b$ content and the increase in the amount of monosaccharides, the main primary products of the photosynthesis dark phase - the Calvin cycle. From biochemical analyses, it was found that the di- and polyamines applied stimulated the monosaccharide content most intensively on the 3rd day, but the chlorophyll content only on the 9th day of $C$. vulgaris culture. These results indicate that di- and polyamines intensively stimulate the dark phase of photosynthesis in a young culture but in an ageing culture the light photosynthesis phase is more stimulated. Proof of this is the intensive stimulation, during this period, of the increase in the amount of chlorophylls $a$ and $b$ and soluble proteins revealing the highest metabolic activity among others in photosynthesis.

Di- and polyamines commonly occur in the cells of all micro and macro-organisms. Data given in literature (Tabor and Tabor 1984; Smith 1985; Scoccianti et al. 1989; Sarjala et al. 1997; Minocha et al. 1999) show that diamines and polyamines intensively stimulate the growth and mitosis of vascular plants and their tissue culture e.g. Helianthus tube- 
rosus, tobacco (Nicotiana tobacum) and algae e.g. Dunaliella primolata and Porphyridium sp. Studies have shown that the most active is spermidine, which in a concentration ranging from 1-100 $\mu \mathrm{M}$ causes intense stimulation of growth of productive tissues, particularly in embriogenesis, callus and plant tumours. In tissue culture of tobacco under the influence of $10-100 \mu \mathrm{M}$ spermidine, a $145-150 \%$ stimulation of cellular growth occurs. Di- and polyamines stimulate the expression of some genes responsible for anabolic processes including those regulating mitosis.

It was found that spermidine not only stimulates the biosynthesis of chlorophylls, but also inhibits their decomposition and stabilisation of chloroplast thylakoid membranes. As a result it causes considerable activation of the process of photosynthesis in its dark and light phases (Pjon et al. 1990).

From publications (Kaur-Sawhney et al. 1982; Shih et al. 1982; Smith 1985; Gniazdowska-Skoczek et al. 1994; Ye et al. 1994; Bajguz and Czerpak 1999; Desideiro et al. 1999 ) it is known that di- and polyamines stimulate the synthesis of ribonucleic acids and proteins by activation of the polymerase of RNA and synthase of aminoacyl-tRNA and stabilisation of ribosomes. Di- and polyamines delay the process of ageing in plants mainly by inhibiting ethylene biosynthesis and weakening the activity of the enzymes: ribonuclease, protease, hydrolase, oxidase and others, which degrade metabolites important for the life of the plant. Di- and polyamines probably play an activating role in the post-translation modifications of plant and, possibly, animal proteins by stimulating specific transglutaminases (Mukhopadhyay et al. 1983; Sen and Ghosh 1984; Bothma and Dubery 1991; Niklas et al. 1998).

The part played by di- and polyamines in the molecular mechanisms regulating the physiological-biochemical processes in cells is very complicated and complex being in close correlation and co-operation with numerous other regulators chiefly the phytohormones activating metabolic processes. These quite extensive regulatory properties of polyamines are due above all to their physicochemical structure which enables them to enter into various interactions with metabolites of vital importance to the plant containing negative electric charges, such as: nucleic acids, proteins, phospholipids, acid saccharides and many others of vital importance to the cells (Kaur-Sawhney et al. 1982; Smith 1985; Schuber 1989; Tiburcio et al. 1997; Laitinen et al. 1998).

From the carried out studies it is seen that di- and polyamines commonly found in plant micro- and macro-organisms, quite intensively stimulate the mitosis in $C$. vulgaris, and increase their protein, chlorophylls and monosaccharide content. The results of the carried out studies on $C$. vulgaris, indicate that the application of di- and polyamines in photosynthesising cells act in the same way in vascular plants as they do in algae commonly occurring in fresh-water ecosystems.

\section{LITERATURE CITED}

BAGNI N. 1997. Polyamine synthesis and accumulation in the hypersensitive response to TMV in Nicotiana tabacum. New Phytol., 135: 467-473.

BOTHMA C., DUBERY I.A. 1991. The effect of polyamines on protein kinase activities of wheat (Triticum aestivum) L. anthers. Plant Growth Regul., 10: 363-375.
BAJGUZ A., CZERPAK R. 1999. Metabolism of polyamines. Kosmos, 48: 67-74. (in Polish)

CZERPAK R., BAJGUZ A. 1999. Physiological and biochemical activity of polyamines in plant adaptation to stresses. Adv. Cell Biol., 26: 523-538 (in Polish).

DAVIS D.G. 1997. Polyamines, auxins and organogenesis in leafy spurge (Euphorbia esula). J. Plant Physiol., 151: 603-609.

DESIDEIRO M.A., DANSI P., TACCHINI L., BERNELLI-ZAZERRA A. 1999. Influence of polyamines on DNA binding of heat shock and activator protein 1 transcription factors induced by heat shock. FEBS Lett., 455: 149-153.

DUREJA-MUNJAL I., ACHARYA M., GUHA-MUKHERJEE S. 1992. Effect of hormones and spermidine on the turnover of inositolphospholipids in Brassica seedlings. Phytochemistry, 31: 1161-1163.

GALSTON A.W., KAUR-SAWHNEY R. 1990. Polyamines in plant physiology. Plant Physiol., 94: 406-410.

GNIAZDOWSKA-SKOCZEK H., KRZYWANSKI Z., KUBIS J. 1994. The influence of exogenous spermidine on polysomes and RNase activity in wheat leaves under water stress conditions. Acta Soc. Bot. Pol., 63: 25-28.

KAKKAR R.K., RAI V.K., NAGAR P.K. 1997/1998. Polyamine uptake and translocation in plants. Biol. Plant., 40: 481-491.

KAUR-SAWHNEY R., SHIH L.M., CEGIELSKA T., GALSTON A.W. 1982. Inhibition of protease activity by polyamines. FEBS Lett., 145: 345-349.

KOTZABASIS K., STRASSER B., NAVAKOUDIS E., SENGER H., DÖRNEMANN D. 1999. The regulatory role of polyamines in structure and functioning of photosynthetic apparatus during photoadaptation. J. Photochem. Photobiol., 50: 45-52.

LAITINEN J., STENIUS K., ELORANTA T.O, HÖLTTA E. 1998. Polyamines may regulate S-phase progression but not the dynamic changes of chromatin during the cell cycle. J. Cell. Biochem., 68: 200-212.

LOWRY P.H., ROSEBROUGH N.I., FARR A.L., RANDALL P.J. 1951. Protein measurment with Folin phenol reagent. J. Biol. Chem., 193: 265-275.

MACCARRONE M., BARONI A., FINAZZI-AGRO A. 1998. Natural polyamines inhibit soybean (Glycine max) lipoxygenase-1, but not the lipoxygenase-2 isozyme. Arch. Biochem. Biophys., 365: 35-40.

MINOCHA R., SMITH D.R., REEVES C., STEELE K.D., MINOCHA S.C. 1999. Polyamine levels during the development of zygotic and somatic embryos of Pinus radiata. Physiol. Plant., 105: 155-164.

MUKHOPADHYAY A., CHOUDHUSI M.M., SEN K., GHOSH B. 1983. Changes in polyamines and related enzymes with loss of viability in rice seeds. Phytochemistry, 22: 1547-1551.

NIKLAS A., BUTOWT R., JAŻDŻEWSKA E., MAJEWSKASAWKA A. 1998. Polyamines in the plant cell: synthesis, mechanisms of action and functions. Adv. Cell Biol., 25: 33- 49 (in Polish).

PIRSON A., LORENZEN H. 1966. Synchronized dividing algae. Annu. Rev. Plant Physiol., 17: 439-458.

PJON C.J., KIM.S.D., PAK J.Y. 1990. Effects of spermidine on chlorophyll content, photosynthetic activity and chloroplast ultrastructure in the dark and under light. Bot. Mag. Tokyo, 103: 43- 48.

PONAPPA T., MILLER A.R. 1996. Polyamines in normal and auxin - induced strawberry fruit development. Physiol. Plant., 98: 447-454.

SARJALA T., HÄGGMAN H., ARONEN T. 1997. Effect of exogenous polyamines and inhibitors of polyamine biosynthesis on growth and free polyamine contents of embryogenic scots pine callus. J. Plant Physiol., 150: 597-602.

SAYEGH A., GREPPIN H. 1973. Chlorella rubescens Ch. essai de synchronisation et mise en evidence de rythmes endogenes. Arch. Sci. Geneve, 8: 6-18. 
SCHUBER F. 1989. Influence of polyamines on membrane functions. Biochem. J., 260: 1-10.

SCOCCIANTI V., BAGNI N., DUBINSKY O., ARAD-MALIS S. 1989. Interaction between polyamines and cells of the marine unicellular red alga Porphyridium sp. Plant Physiol. Biochem., 27: 899-904.

SEN K., GHOSH B. 1984. Effect of polyamines on ribonuclease activity of rice (Oryza sativa L.). Phytochemistry, 23: 1583$-1585$.

SHIH L.M., KAUR-SAWHNEY R., FUHRER J., SAMANTA S., GALSTON A.W. 1982. Effects of exogenous 1,3- diaminopropane and spermidine on senescence of oat leaves. Plant Physiol., 70: 1592-1596.

SMITH T.A. 1985. Polyamines. Annu. Rev. Plant Physiol., 36: 117-143.

SOMOGYI M. 1954. Notes on sugar determination. J. Biol. Chem., 195: 19-23.
TABOR C.W., TABOR H. 1984. Polyamines. Annu. Rev. Biochem., 53: 749-790.

TIBURCIO A.F., ALTABELLA T., BORREL A., MASGRAU C. 1997. Polyamines metabolism and its regulation. Physiol. Plant., 100: 664-674.

VAN DEN BROECK D., VAN DEN STRAETEN D., VAN MONTAGU M., APLAN A. 1994. A group of chromosomal proteins is specifically released by spermine and loses DNA-binding activity upon phosphorylation. Plant Physiol., 106: 559-566.

WELLBURN A.R. 1994. The spectral determination of chlorophylls $a$ and $b$, as well as total carotenoids, using various solvents with spectrophotometers of different resolution. J. Plant Physiol., 144: 307-313.

YE X.S., AVDIUSHKO S.A., KUC J. 1994. Effects of polyamines on in vitro phosphorylation of soluble and plasma membrane proteins in tobacco, cucumber and Arabidopsis thaliana. Plant Sci., 97: 109-118.

\section{BIOCHEMICZNA AKTYWNOŚĆ DI- I POLIAMIN W ZIELENICY CHLORELLA VULGARIS BEIJERINCK (CHLOROPHYCEAE)}

\section{STRESZCZENIE}

Badano wpływ diamin (agmatyny, putrescyny) i poliamin (sperminy, spermidyny) na wzrost i zawartość chlorofilu $a$ i $b$, monosacharydów, białek w komórkach glonu Chlorella vulgaris Beijerinck (Chlorophyceae). W doświadczeniu zastosowano agmatynę, putrescynę, sperminę i spermidynę w zakresie stężeń $10^{-6}-10^{-3} \mathrm{M}$. Di- i poliaminy w stężeniu $10^{-3} \mathrm{M}$ od pierwszego dnia hodowli miały toksyczny wpływ na wzrost glonu. Stwierdzono, że di- i poliaminy stosowane w zakresie stężeń $10^{-6}-10^{-4} \mathrm{M}$ stymulują wzrost zawartości analizowanych parametrów biochemicznych w komórkach $C$. vulgaris. Spermidyna i putrescyna w stężeniu $10^{-4} \mathrm{M}$ wykazały najbardziej stymulujący wpływ na metabolizm zielenicy. Agmatyna i spermina charakteryzowały się niższą aktywnością biologiczną niż spermidyna i putrescyna.

SŁOWA KLUCZOWE: Chlorella vulgaris, di- i poliaminy, wzrost, chlorofile, monosacharydy, białka. 